\section{Dirhodium(II) Tetraacetamidate}

\author{
$\mathrm{Rh}_{2}(\mathrm{NHCOMe})_{4}$ \\ [87985-40-8] $\quad \mathrm{C}_{8} \mathrm{H}_{16} \mathrm{~N}_{4} \mathrm{O}_{4} \mathrm{Rh}_{2} \quad$ (MW 438.10) \\ $\mathrm{InChI}=1 \mathrm{~S} / 4 \mathrm{C} 2 \mathrm{H} 5 \mathrm{NO} .2 \mathrm{Rh} / \mathrm{c} 4 * 1-2(3) 4 ; ; / \mathrm{h} 4 * 1 \mathrm{H} 3,(\mathrm{H} 2,3,4) ; ; /$ \\ $\mathrm{q} ; ; ; ; 2 *+2 / \mathrm{p}-4$ \\ InChIKey $=$ VKOXSPVYCVPFMU-UHFFFAOYSA-J
}

(catalyst for selective carbenoid reactions of diazo compounds ${ }^{\mathbf{1}}$ )

Alternate Name: dirhodium(II) tetraacetamidate.

Physical Data: UV/vis (MeCN) 500 (2.2), 345 (shoulder) nm. ${ }^{2}$

NMR $\left(\mathrm{CD}_{3} \mathrm{CN}\right): \delta 2.20(\mathrm{~s})^{3}$

Spectral Data: $\lambda$ 500, 345 (shoulder) $\mathrm{nm}\left(\mathrm{CH}_{3} \mathrm{CN}\right){ }^{2}{ }^{1} \mathrm{H}$ NMR

$\left(\mathrm{CD}_{3} \mathrm{CN}\right)$ of $\mathrm{Rh}_{2}(\mathrm{acam})_{4}-\left(\mathrm{CH}_{3} \mathrm{CN}\right)_{2}: \delta 2.20(\mathrm{~s}, 12 \mathrm{H})$.

Solubility: sol MeOH, MeCN, pyridine, DMSO; insol $\mathrm{CH}_{2} \mathrm{Cl}_{2}$, $\mathrm{ClCH}_{2} \mathrm{CH}_{2} \mathrm{Cl}$, toluene.

Form Supplied in: blue solid for anhydrous form and after removal of axial nitrile ligands; purple solid as hydrate and as the bisacetonitrile complex.

Preparative Method: from dirhodium tetraacetate by ligand substitution with acetamide (eq 1). ${ }^{3}$

Handling, Storage, and Precautions: air stable, weakly hygroscopic; stored in desiccator.

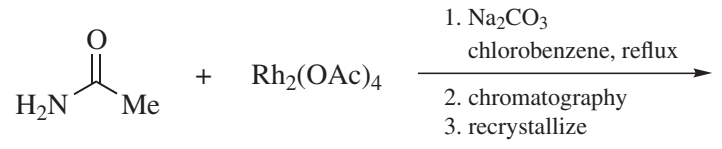

(4.0 equiv)

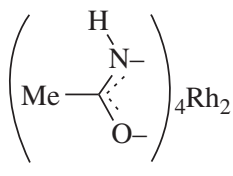

$$
\mathrm{Rh}_{2}(\mathrm{acam})_{4}
$$

\section{Original Commentary}

Michael P. Doyle

University of Maryland, College Park, MD, USA

Introduction. Dirhodium(II) tetraacetamide, $\mathrm{Rh}_{2}(\text { acam })_{4}$, was first prepared from Dirhodium(II) Tetraacetate in a melt of acetamide. ${ }^{4}$ However, this method gave a mixture of $\mathrm{Rh}_{2}(\mathrm{OAc})_{4-n}(\mathrm{acam})_{n}$, of which $\mathrm{Rh}_{2}(\text { acam })_{4}$ was the dominant product but could not be conveniently separated. The preferred procedure is to treat $\mathrm{Rh}_{2}(\mathrm{OAc})_{4}$ with acetamide in refluxing chlorobenzene under conditions where acetic acid is trapped by sodium carbonate in a Soxhlet extraction apparatus (eq 2). ${ }^{3}$ Four acetamidates are ligated to one dirhodium(II) nucleus, and each rhodium is bound to two nitrogen and two oxygen donor atoms arranged in a cis geometry. ${ }^{\mathbf{5}}$ Incomplete substitution, when only three acetamides have replaced acetate, yielding $\mathrm{Rh}_{2}(\mathrm{acam})_{3}(\mathrm{OAc})$, produced a catalyst whose selectivity is not optimum.

$$
\mathrm{Rh}_{2}(\mathrm{OAc})_{4}+4 \mathrm{MeCONH}_{2} \stackrel{\mathrm{PhCl}}{\longrightarrow} \underset{\mathrm{Rh}-\mathrm{Rh}_{1}}{\mathrm{Rh}}+4 \mathrm{AcOH} \text { (2) }
$$

Metal Carbene Transformations. Although insoluble in the solvents in which catalytic metal carbene transformations are performed, $\mathrm{Rh}_{2}(\mathrm{acam})_{4}$ enters solution after addition of the diazo compound. The principal advantage of this catalyst is its selectivity for product formation from reactions with diazocarbonyl compounds, but its reactivity towards dinitrogen extrusion is less than that of dirhodium(II) tetra(carboxylates).

Stereoselectivity in Cyclopropanation Reactions. Use of $\mathrm{Rh}_{2}$ (acam) $)_{4}$ for intermolecular cyclopropanation of alkenes results in higher trans (anti) selectivity which, when the diazo compound is 2,6-di-t-butyl-4-methylphenyl diazoacetate (BDA), is exceptional (e.g. eq 3: $98 \%$ trans). ${ }^{3}$ Product yields are high (75-96\%), and byproducts are often minimal. Relative reactivities are also enhanced by $\mathrm{Rh}_{2}(\mathrm{acam})_{4}$, which has made possible highly regioselective cyclopropanation of selected dienes (e.g. eq 4). ${ }^{3}$ However, $\mathrm{Rh}_{2}(\text { acam })_{4}$ is unsuitable, relative to Dirhodium(II) Tetraacetate, for intermolecular cyclopropanation of styrene by the pantolactone ester of trans-2-diazo-4-phenyl-3-butenoate. ${ }^{6}$ Substitution of $\mathrm{Rh}_{2}(\text { acam })_{4}$ by the more soluble Dirhodium(II) Tetra(caprolactam), $\mathrm{RH}_{2}$ (cap) $)_{4}$, does not provide any obvious advantage in reactivity or selectivity for cyclopropanation.
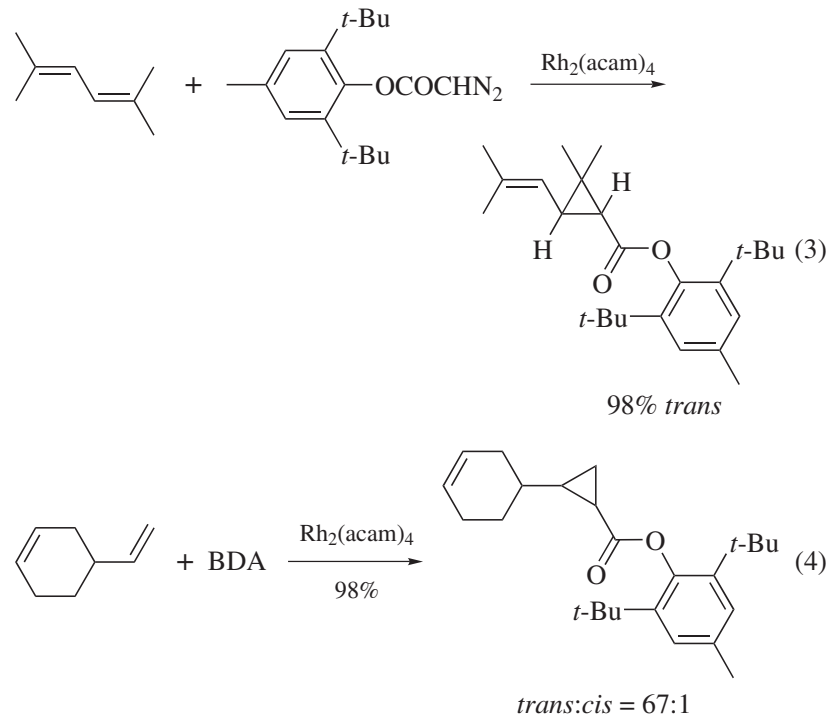

Carbon-Hydrogen Insertion Reactions. Use of $\mathrm{Rh}_{2}(\mathrm{acam})_{4}$ provides an increase in regioselectivity for competitive insertion into carbon-hydrogen bonds (tertiary $>$ secondary $>$ primary) that result in the formation of five-membered ring carbonyl compounds (e.g. eq $5 ; \mathrm{pfb}=$ perfluorobutyrate) ${ }^{7,8}$

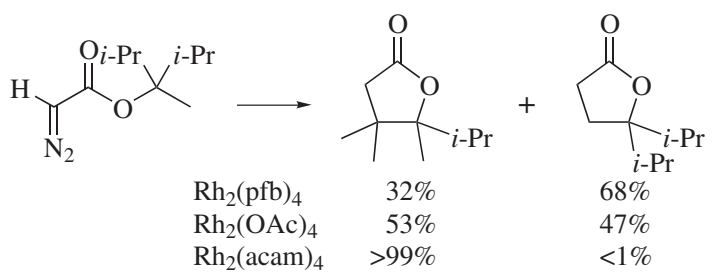


Both diazoacetoacetates and diazoacetates show exceptional selectivity enhancement with $\mathrm{Rh}_{2}(\mathrm{acam})_{4}$. However, the same degree of control is not evident in the competition from diazoacetoacetamides for $\beta$-lactam versus $\gamma$-lactam formation. ${ }^{\text {9-11 }}$ The use of $\mathrm{Rh}_{2}(\text { cap })_{4}$ in place of $\mathrm{Rh}_{2}(\mathrm{acam})_{4}$ does not provide any obvious advantage in regioselectivity for carbon-hydrogen insertion.

Chemoselectivity. Few comparisons have been made with $\mathrm{Rh}_{2}(\text { acam })_{4}$ and $\mathrm{Rh}_{2}(\mathrm{cap})_{4}$, but those that have suggest that $\mathrm{Rh}_{2}(\text { cap })_{4}$ holds an advantage. ${ }^{11} \mathrm{~N}$-(2-Arylethyl)- $N$ - $t$ butyldiazoacetamides, for example, exhibit competition between aromatic cycloaddition and carbon-hydrogen insertion (e.g. eq 6), and chemoselectivity for $\mathrm{C}-\mathrm{H}$ insertion with $\mathrm{Rh}_{2}$ (cap) is greater than with $\mathrm{Rh}_{2}(\mathrm{acam})_{4}$, but both are more selective than is $\mathrm{Rh}_{2}(\mathrm{OAc})_{4}$.

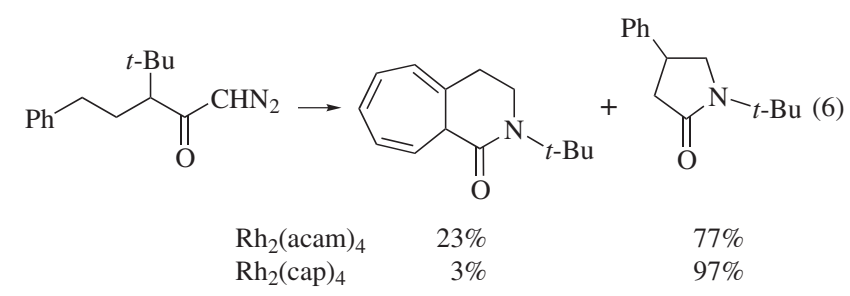

\section{First Update}

Michael P. Doyle \& Raymond E. Forslund

University of Maryland, College Park, MD, USA

Preparation. Dirhodium(II) tetraacetamidate, $\mathrm{Rh}_{2}(\text { acam })_{4}$, was first prepared from dirhodium(II) tetraacetate in a melt of acetamide. ${ }^{4}$ However, this method gave a mixture of $\mathrm{Rh}_{2}(\mathrm{OAc})_{4-n}(\mathrm{acam})_{n}$. The preferred procedure is ligand substitution on $\mathrm{Rh}_{2}(\mathrm{OAc})_{4}$ with acetamide in refluxing chlorobenzene; liberated acetic acid is trapped by sodium carbonate in a Soxhlet extraction apparatus. ${ }^{3}$ Four acetamide molecules ligate one dirhodium(II) nucleus; each rhodium is bound to two nitrogen and two oxygen donor atoms arranged in a cis-geometry. 5

Carbon-Hydrogen Insertion Reactions. Rhodium(II)catalyzed reaction of $\alpha^{\prime}, \alpha^{\prime}$ - $O$-alkyl- $\alpha$-(alkoxycarbonyl)- $\alpha$ diazoacetates (eq 7, Table 1) showed that insertion into the tertiary $\mathrm{C}-\mathrm{H}$ bond was the preferred pathway, however, when $\mathrm{R}=$ acetyl, a modest preference was observed for $\mathbf{1 . 1 2}$

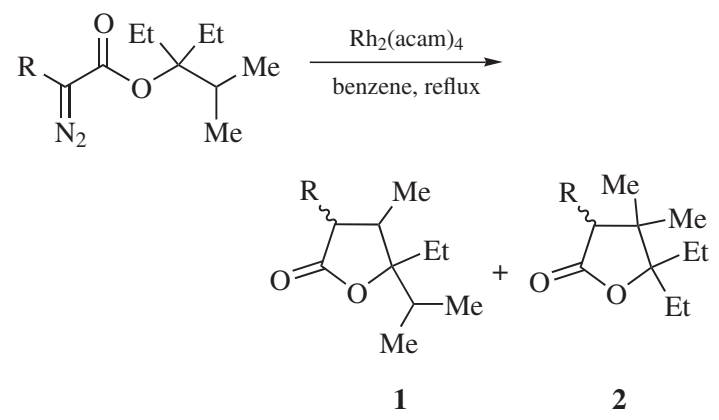

Table 1 Dirhodium(II) tetraacetamidate-catalyzed C-H insertion of $\alpha^{\prime}, \alpha^{\prime}$ $O$-alkyl- $\alpha$-(alkoxycarbonyl)- $\alpha$-diazoacetates

\begin{tabular}{lcc}
\hline $\mathrm{R}$ & Isolated Yield & Relative Yield (1:2) \\
\hline $\mathrm{CO}_{2} \mathrm{Me}$ & 90 & $42: 58$ \\
$\mathrm{CO}_{2} \mathrm{CH}_{2} \mathrm{CF}_{3}$ & 87 & $41: 59$ \\
$\mathrm{C}(\mathrm{O}) \mathrm{CH}_{3}$ & 83 & $77: 23$ \\
\hline
\end{tabular}

When $\mathrm{Rh}_{2}(\text { acam })_{4}$ was used in competition reactions between cyclopropanation and $\mathrm{C}-\mathrm{H}$ insertion reactions (eq 8, Table 2); cyclopropanation of the double bond was the major pathway when $n=1$ and also accounted for a significant amount of product when $n=2$. This observation is in agreement with previous findings that have shown that amide-based catalysts favor cyclopropanation over tertiary $\mathrm{C}-\mathrm{H}$ insertion. ${ }^{\mathbf{1 3}}$

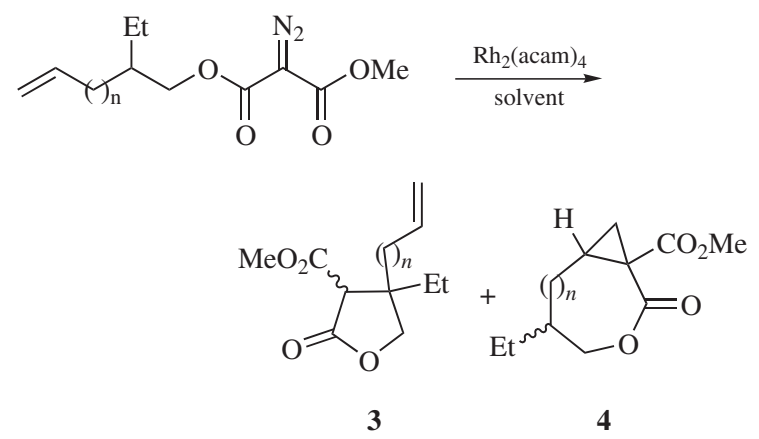

Table 2 C-H Insertion versus cyclopropanation with dirhodium(II) tetraacetamidate

\begin{tabular}{ccccc}
\hline$n$ & Solvent & Temp $\left({ }^{\circ} \mathrm{C}\right)$ & Yield (\%) & Relative Yield (3:4) \\
\hline 1 & $\mathrm{CH}_{2} \mathrm{Cl}_{2}$ & 25 & 80 & $29: 60$ \\
1 & benzene & 25 & 62 & $34: 66$ \\
2 & $\mathrm{CH}_{2} \mathrm{Cl}_{2}$ & 40 & 87 & $73: 26$ \\
\hline
\end{tabular}

Other. Wang and co-workers have used $\mathrm{Rh}_{2}(\text { acam })_{4}$ and other dirhodium catalysts to probe for mechanistic details concerning the metal-mediated intramolecular metal carbene $\mathrm{C}-\mathrm{H}$ insertion reaction ${ }^{\mathbf{1 4}}$ as well as reactivities of $\alpha$-diazo esters towards these catalysts. $^{15}$

\section{Second Update}

Thomas Lecourt \& Antoine Joosten Normandy University, Rouen, France

Preparation. Dirhodium(II) tetraacetamidate, $\mathrm{Rh}_{2}(\mathrm{acam})_{4}$, can be immobilized on a Argopore resin functionalized with a Wang linker ended by a pyridine ligand (eq 9). ${ }^{\mathbf{1 6}}$ contrary to bulky $\mathrm{Rh}$ (II) catalysts, immobilization of small species like $\mathrm{Rh}_{2}(\mathrm{acam})_{4}$ or $\mathrm{Rh}_{2}(\mathrm{OAc})_{4}$ is less efficient, and the catalytic activity of these materials is thus markedly reduced.

Although the polymer backbone, the linker, and the ligand are all important for efficient loading of the Rh(II) dimers, microencapsulation of the complexes into the reticulated macromolecular structure is also critical for high catalytic activity and efficient recycling. 


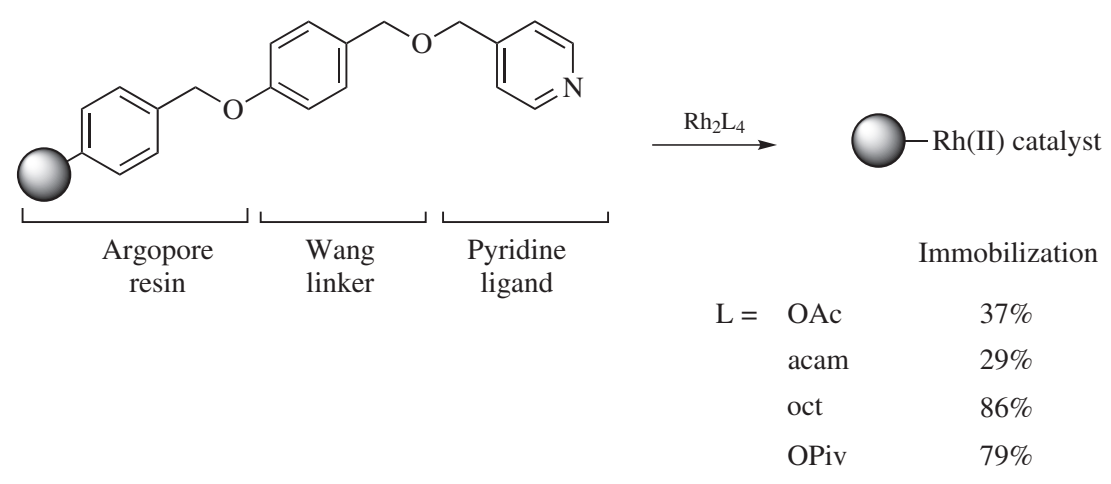

Metal Carbene Transformations. Use of $\mathrm{Rh}_{2}(\text { acam })_{4}$ to catalytically decompose diazo compounds generates less electrophilic metal carbenes than with dirhodium(II) carboxylates because of the stronger $\pi$ backdonation that stabilizes the empty p-orbital of the carbenoid species. This decreased reactivity of the $\mathrm{Rh}$ (II)-carbene results in modifications of the product distribution when cyclopropanation and $\mathrm{C}-\mathrm{H}$ insertion are competitive, ${ }^{\mathbf{1 7}}$ favors 1,2 phenyl migration over hydride shift, ${ }^{\mathbf{1 8}}$ and delivers lower yields of $\gamma$-lactams from diazo amides. ${ }^{19}$

Chemo- and Regioselective $\mathrm{C}-\mathrm{H}$ Insertion Reactions. $\mathrm{Rh}_{2}$ (acam) $)_{4}$ can restore a high level of regio- and chemoselectivity for $\mathrm{C}-\mathrm{H}$ insertion processes when dirhodium(II) carboxylates are giving rise to complex mixtures. Decomposition of diazo compounds made by condensation of Ti(IV) enolates with cycloalkanones, followed by elimination by $\mathrm{Rh}_{2}(\text { acam })_{4}$ cleanly gives highly valuable bicyclic fused cyclopentenones in contrast to dirhodium(II) tetraacetate (eq 10). ${ }^{\mathbf{2 0}}$
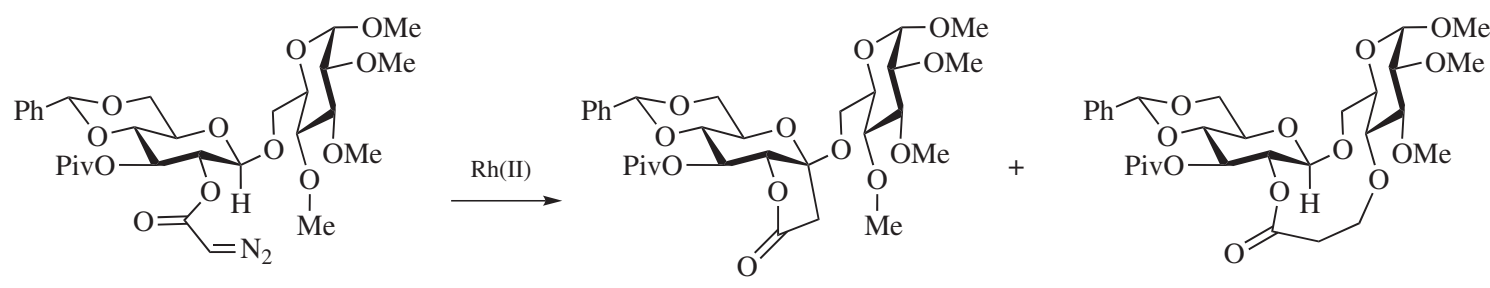

Dirhodium(II) tetraacetamidate is also essential to achieve se-
lective functionalization of complex carbohydrate scaffolds. Because of subtle electronic effects, ${ }^{22}$ axial anomeric $\mathrm{C}-\mathrm{H}$ bonds are reactive enough to suffer insertion of metal carbenes having a low reactivity. Under $\mathrm{Rh}_{2}(\text { acam })_{4}$ catalysis, decomposition of a diazo $\beta$-glucoside thus selectively delivers the expected $\gamma$ lactone, whereas dirhodium(II) tetraacetate results in competitive 1,11-C-H insertion into the reducing end of the disaccharide (eq 11). ${ }^{23}$

$\begin{array}{lccc} & 1,5-\mathrm{C}-\mathrm{H} & 1,11-\mathrm{C}-\mathrm{H} & \\ \mathrm{Rh}_{2}(\mathrm{OAc})_{4} & 50 & 50 & 94 \% \\ \left.\mathrm{Rh}_{2} \text { (acam }\right)_{4} & 100 & 0 & 61 \%\end{array}$

Ylide-mediated Transformations. The ability of $\mathrm{Rh}(\mathrm{II})-$ carbenes to form ylides with lone pairs is opening the way to large molecular diversity. [3+2] cycloaddition of a carbonyl ylide with 3-butyn-2-one provides a straightforward access to the polycyclic core of zaragozic acid C (eq 12). ${ }^{24}$ The stereoselectivity of [3+2] cycloadditions involving carbonyl ylides can be modified by switching from $\mathrm{Rh}_{2}(\mathrm{OAc})_{4}$ to $\mathrm{Rh}_{2}(\text { acam })_{4} \cdot{ }^{25}$

$\mathrm{Rh}_{2}(\mathrm{acam})_{4}$ also cleanly induces the formal insertion of carbenes into the $\mathrm{C}-\mathrm{N}$ bond of amides (eq 13). ${ }^{26}$ This transformation may initially involve formation of an ammonium ylide, followed by a selective 1,2 migration triggered by $\mathrm{H}$-bonding of the acyl group to an acetamidate ligand. Use of the more bulky $\mathrm{Rh}_{2}(\mathrm{NHCOtBu})_{4}$ improves the efficiency of this transformation 

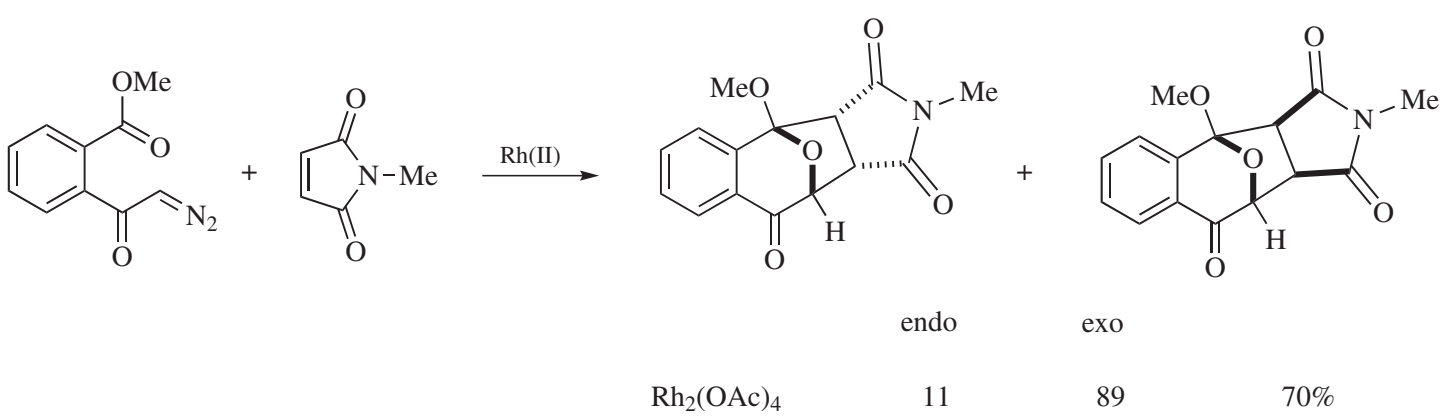

$\begin{array}{llll}\mathrm{Rh}_{2}(\mathrm{acam})_{4} & 35 & 65 & 61 \%\end{array}$

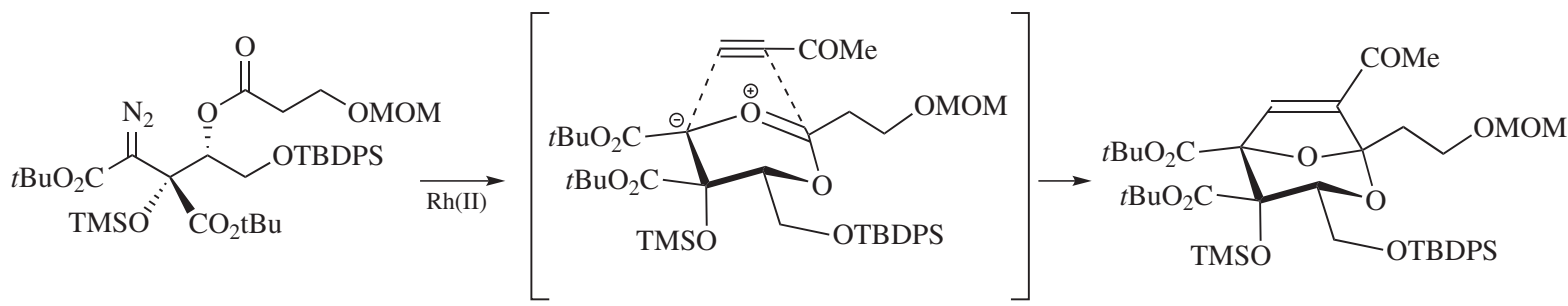

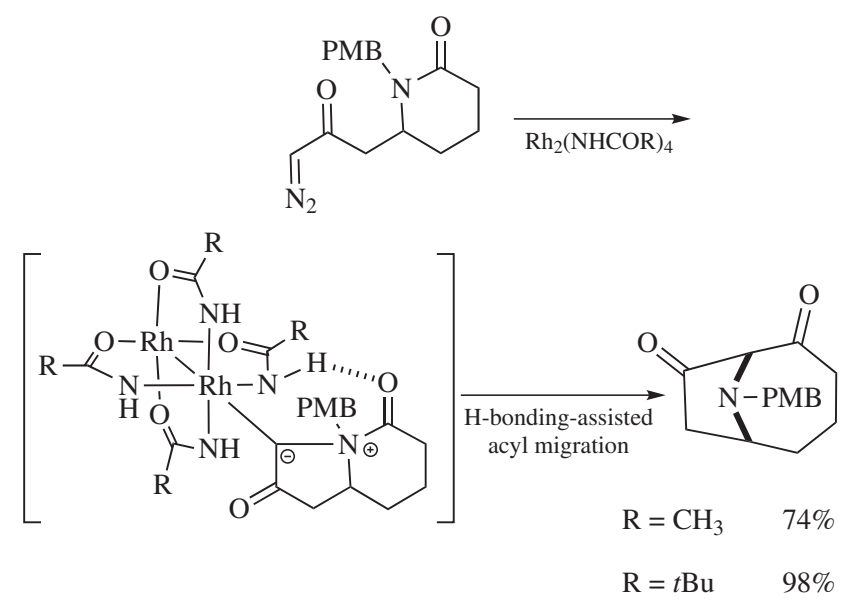

(13) that affords access to various nitrogen-bridged bicyclic frameworks.

Multidimentional Metallic Architectures. Assemblages of the paddle wheel $\mathrm{Rh}_{2}(\text { acam })_{4}$ with dinuclear platinum complexes or halogen ions give rise to multidimensional networks with high potency as functional materials.

One-dimensional Heterometallic Chains Formed with Platinum Complexes. One-dimensional (1D) chain complexes made of dirhodium $\left([\mathrm{Rh}]_{2}\right)$ and diplatinum $\left([\mathrm{Pt}]_{2}\right)$ metallic complexes with bridging ligands have recently been reported. Their formation is driven by the establishment of (1) metal-metal bonds between $[\mathrm{Rh}]_{2}$ and $[\mathrm{Pt}]_{2}$ units through HOMO-LUMO interactions between the $d_{z}$-orbitals of $\operatorname{Rh}(\mathrm{II})$ and $\mathrm{Pt}(\mathrm{II})$ centers and (2) a hydrogen bond network that depends on nature and orientation of the ligands.

$$
\begin{aligned}
& \text { Head-to-head } \\
& \text { bridging ligand }
\end{aligned}
$$

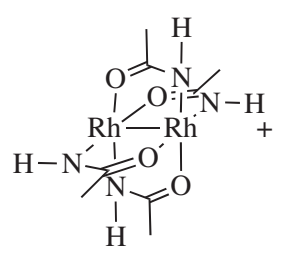

$$
\begin{aligned}
& t \mathrm{Bu} \\
& \overbrace{1}^{2} t \mathrm{Bu} \\
& \begin{array}{l}
1 \mathrm{HN}-1 \leqslant \\
\mathrm{Pt}^{\prime}-\mathrm{Pt}^{\prime}
\end{array} \\
& \mathrm{H}_{3} \mathrm{~N}^{\prime} \mathrm{H}_{3} \mathrm{~N}^{\prime} \\
& \mathrm{H}_{3} \mathrm{~N} \quad \mathrm{NH}_{3} \\
& \text { \& } \\
& +\overbrace{1,2}^{t \mathrm{Bu}} \\
& \mathrm{Pt}^{\prime}-\mathrm{Pt}^{\prime} \\
& \mathrm{H}_{3} \mathrm{~N} \quad \mathrm{NH}_{3} \\
& \text { Head-to-tail } \\
& \text { bridging ligand }
\end{aligned}
$$

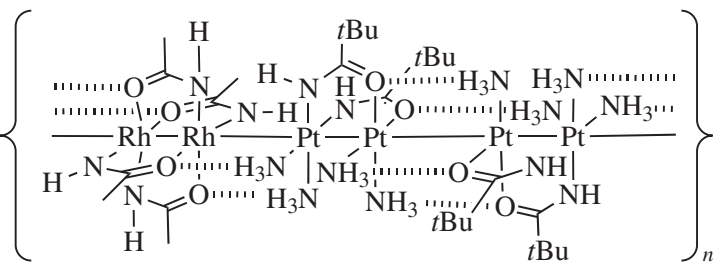

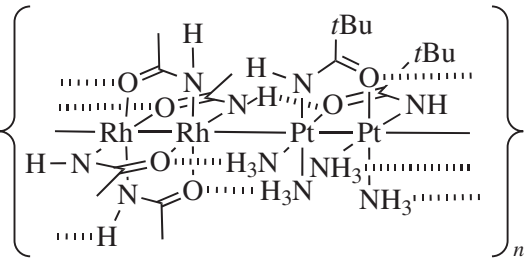


The bridging ligand in $[\mathrm{Rh}]_{2}$, the coligand of $[\mathrm{Pt}]_{2}$, and the bridging ligand of $[\mathrm{Pt}]_{2}$ control the sequence of $[\mathrm{Rh}]_{2}$ and $[\mathrm{Pt}]_{2}$ segments. They give rise to different repeating units depending on the number and orientation of $\mathrm{H}$-bond donor and acceptor binding sites (eq 14). With $\left[\mathrm{Pt}_{2}(\text { piam })_{2}\left(\mathrm{NH}_{3}\right)_{4}\right]^{2+}($ piam $=$ pivalamidate $)$ as platinum core, both crystallographic structures and electronic spectra of molecular wires made with $\mathrm{Rh}_{2}(\mathrm{acam})_{4}$ differ from those incorporating dirhodium acetate and trifluoroacetate. ${ }^{27} 1 \mathrm{D}$ chain complexes with either $\left\{[\mathrm{Rh}]_{2}-[\mathrm{Pt}]_{2}-[\mathrm{Pt}]_{2}\right\}$ or $\left\{[\mathrm{Rh}]_{2}-[\mathrm{Pt}]_{2}\right\}$ repeating units can be obtained depending on the head-to-head or head-to-tail orientation of the two pivalamidate ligands of the $\left[\mathrm{Pt}_{2}\right]$ core (eq 14). ${ }^{28}$ Switching to a pivalate bridging ligand for $\left[\mathrm{Pt}_{2}\right]$ gives a $1 \mathrm{D}$ chain complex having a $\left\{[\mathrm{Rh}]_{2}-[\mathrm{Pt}]_{2}-[\mathrm{Rh}]_{2}-[\mathrm{Pt}]_{2^{-}}\right.$ $\left.[\mathrm{Rh}]_{2}-[\mathrm{Pt}]_{2}-[\mathrm{Pt}]_{2}\right\}$ monomeric unit. ${ }^{29}$ whereas complexes with strongly electron-withdrawing ligands do not block transcription in absence of this enzyme. Different binding modes to biomolecules are thus expected for Rh(II) dimers depending on their axial reactivity that is modulated by $\pi$ backbonding.

The head-to-head and head-to-tail $\left[\mathrm{Rh}_{2}(\mathrm{acam})_{2}\left(\mathrm{CH}_{3} \mathrm{CN}\right)_{6}\right]^{2+}$ complexes can be prepared by treatment of $\mathrm{Rh}_{2}(\text { acam })_{4}$ with trimethyloxonium tetrafluoroborate in $\mathrm{CH}_{3} \mathrm{CN}$ (eq 15). ${ }^{33}$ Visible light irradiation of aqueous solutions of these cationic species results in exchange of two equatorial acetonitrile ligands by water molecules to give a bis-aqua complex, whose selective binding to double-stranded DNA is opening the way to applications in photodynamic therapy.

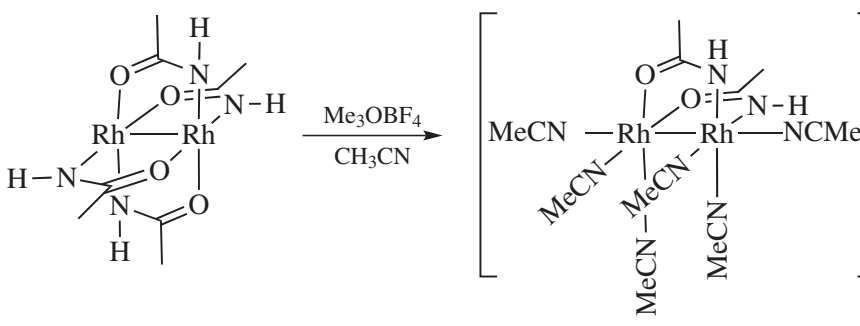

Multidimensional Molecular Architectures Formed with Halogen Bridging ligands. Halide ions can give various molecular architectures by bridging neutral and cationic dirhodium tetraacetamidate complexes. While cationic $\left[\mathrm{Rh}_{2}(\mathrm{acam})_{4}\right]^{+}$forms $1 \mathrm{D}$ chain structures with chloride, bromide, or iodine, mixtures of $\left[\mathrm{Rh}_{2}(\mathrm{acam})_{4}\right]^{+}$and $\left[\mathrm{Rh}_{2}(\mathrm{acam})_{4}\right]^{0}$ with halide ions result in the formation of two-dimensional (2D) honeycomb sheet arrangements of $\left[\left\{\mathrm{Rh}_{2}(\mathrm{acam})_{4}\right\}_{3}\left(\mu_{3}-\mathrm{Cl} / \mathrm{Br} / \mathrm{I}\right)_{2}\right] \cdot 4 / 10 / 10 \mathrm{H}_{2} \mathrm{O}$ monomeric units. ${ }^{30}$ Iodide can also give a three-dimensional (3D) diamondoid structure $\left[\left\{\mathrm{Rh}_{2}(\text { acam })_{4}\right\}_{2}\left(\mu_{4}-\mathrm{I}\right)\right] \cdot 6 \mathrm{H}_{2} \mathrm{O}_{n} \cdot{ }^{31}$ The conductivity of these mixed oxidation state complexes is high for the latter and for $\left[\left\{\mathrm{Rh}_{2}(\mathrm{acam})_{4}\right\}_{3}\left(\mu_{3}-\mathrm{Br} / \mathrm{I}\right)_{2}\right] \cdot 10 \mathrm{H}_{2} \mathrm{O}$, where all the rhodium atoms are crystallographically equivalent. The chlorine-bridged honeycomb sheet structure, whose repeating unit has one $\mathrm{Rh}_{2}^{4+}$ and two $\mathrm{Rh}_{2}^{5+}$ cores, has lower conductivity. Dehydration of these complexes by loss of $\mathrm{H}$-bonded water molecules results in a large increase of the conductivity of these materials, with an oscillation over a range of $10^{5}{\mathrm{~S} . \mathrm{cm}^{-1}}_{\text {for the diamondoid structure. }}{ }^{\mathbf{3 0 , 3 1}}$

Interactions with Nucleic Acids. Rhodium compounds also attracted considerable interest because of their potential antineoplastic activity. Based on modifications of the redox potential of $\mathrm{Rh}$ (II) dimers, and on the shift or suppression of the adenine and guanine oxidation peaks, electrochemical methods can be used to monitor the binding of DNA to the free axial coordination sites of di-rhodium(II) complexes. ${ }^{32}$ Although the electrochemical techniques do not provide quantitative data, they reveal that $\mathrm{Rh}_{2}(\mathrm{acam})_{4}$ binds preferentially to guanine, in contrast to rhodium carboxylates that are selective for adenine. The nature of the ligands spanning the Rh(II) dimers also influences their ability to perturb the transcription machinery in vitro. ${ }^{33}$ Inhibition by $\mathrm{Rh}_{2}(\mathrm{acam})_{4}$ is independent from binding to RNA polymerase,

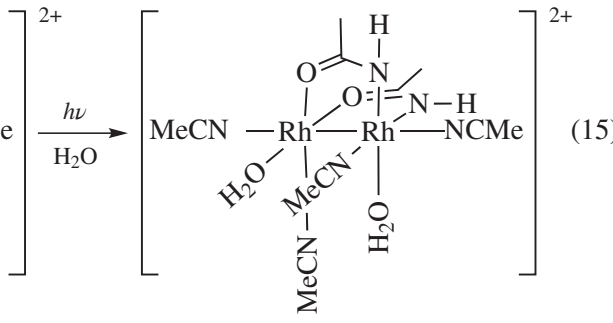

Binding to double-stranded DNA

1. Doyle, M. P. In Homogenous Transition Metal Catalyzed Reactions; Moser, W. R.; Slocum, D. W., Eds.; American Chemical Society: Washington, 1992.

2. Chavan, M. Y.; Zhu, T. P.; Lin, X. Q.; Ahsan, M. Q.; Bear, J. L.; Kadish, K. M., Inorg. Chem. 1984, 23, 4538.

3. Doyle, M. P.; Bagheri, V.; Wandless, T. J.; Harn, N. K.; Brinker, D. A.; Eagle, C. T.; Loh, K. -L., J. Am. Chem. Soc. 1990, 112, 1906.

4. (a) Zhu, T. P.; Ahsan, M. Q.; Malinski, T.; Kadish, K. M.; Bear, J. L., Inorg. Chem. 1984, 23, 2. (b) Best, S. P.; Chandley, P.; Clark, R. J. H.; McCarthy, S.; Hursthouse, M. B.; Bates, P. A., J. Chem. Soc., Dalton Trans. 1989, 581.

5. Ahsan, M. Q.; Bernal, I.; Bear, J. L., Inorg. Chem. 1986, 25, 260.

6. Davies, H. M. L.; Cantrell, W. R., Jr., Tetrahedron Lett. 1991, 32, 6509.

7. Doyle, M. P.; Bagheri, V.; Pearson, M. M.; Edwards, J. D., Tetrahedron Lett. 1989, 30, 7001.

8. Doyle, M. P.; Westrum, L. J.; Wolthuis, W. N. E.; See, M. M.; Boone, W. P.; Bagheri, V.; Pearson, M. M., J. Am. Chem. Soc. 1993, 115, 958.

9. Doyle, M. P.; Taunton, J.; Pho, H. Q., Tetrahedron Lett. 1989, 30, 5397.

10. Doyle, M. P.; Pieters, R. J.; Taunton, J.; Pho, H. Q.; Padwa, A.; Hertzog, D. L.; Precedo, L., J. Org. Chem. 1991, 56, 820.

11. Padwa, A.; Austin, D. J.; Price, A. T.; Semones, M. A.; Doyle, M. P.; Protopopova, M. N.; Winchester, W. R.; Tran, A., J. Am. Chem. Soc. 1993, 115, 8669.

12. Wee, A.; Yu, Q., J. Org. Chem. 1997, 62, 3324.

13. (a) Doyle, M. P.; Bagheri, V.; Wanderless, T. J.; Ham, N. K.; Brinker, D. A.; Eagle, L. T.; Loh, K.-L., J. Am. Chem Soc., 1990, 112, 1906. (b) Doyle, M. P.; Loh, K.-L.; Dervies, K. M.; Chinn, M. S., Tetrahedron Lett., 1987, 28, 833

14. Wang, J.; Chen, B.; Bao, J., J. Org. Chem., 1998, 63, 1853.

15. Qu, Z.; Shi, W.; Wang, J., J. Org. Chem., 2001, 66, 8139.

16. Davies, H. M. L.; Walji, A. M.; Nagashima, T., J. Am. Chem. Soc. 2004, $126,4271$. 
17. (a) Clark, J. S.; Dosseter, A. G.; Wong, Y.-S.; Townsen, R. J.; Whittingham, W. G.; Russell, C. A., J. Org. Chem. 2004, 69, 3886. (b) Shi, W.; Xia, F.; Wang, J., J. Org. Chem. 2005, 70, 4318.

18. (a) Jiang, N.; Qu, Z.; Wang, J., Org. Lett. 2001, 3, 2989. (b) Jiang, N.; Ma, Z.; Qu, Z.; Xing, X.; Xie, L.; Wang, J., J. Org. Chem. 2003, 68, 893.

19. Wee, A. G.; Duncan, S., Tetrahedron Lett. 2002, 43, 6173.

20. Deng, G.; Tian, X.; Wang, J., Tetrahedron Lett. 2003, 44, 587.

21. Boultadakis-Arapinis, M.; Lemoine, P.; Turcaud, S.; Micouin, L.; Lecourt, T., J. Am. Chem. Soc. 2010, 132, 15477.

22. Boultadakis-Arapinis, M.; Gandon, V.; Prost, E.; Micouin, L.; Lecourt, T., Adv. Synth. Cat. 2014, 359, 2493.

23. Boultadakis-Arapinis, M.; Prost, E.; Gandon, V.; Lemoine, P.; Turcaud, S.; Micouin, L.; Lecourt, T., Chem. Eur. J. 2013, 19, 6052.

24. Nakamura, S.; Hirata, Y.; Kurosaki, T.; Anada, M.; Kataoka, O.; Kitagaki, S.; Hashimoto, S., Angew. Chem., Int. Ed. 2003, 42, 5351.

25. Suga, H.; Kakehi, A.; Ito, S.; Inoue, K.; Ishida, H.; Ibata, T., Bull. Chem. Soc. Jpn. 2001, 74, 1115.
26. Harada, S.; Kono, M.; Nozaki, T.; Menjo, Y.; Nemoto, T.; Hamada, Y., J. Org. Chem. 2015, 80, 10317.

27. Uemura, K.; Ebihara, M., Inorg. Chem. 2011, 50, 7919.

28. Uemura, K.; Kanbara, T.; Ebihara, M., Inorg. Chem. 2014, 53, 4621.

29. Yamada, T.; Ebihara, M.; Uemura, K., Dalton Trans. 2016, 45, 12322.

30. Fuma, Y.; Miyashita, O.; Kawamura, T.; Ebihara, M. Dalton Trans. 2012, 41, 8242.

31. Fuma, Y.; Ebihara, M.; Kutsumizu, S.; Kawamura, T., J. Am. Chem. Soc. 2004, 126, 12238.

32. Gil, E. S.; Serrano, S. P. H.; Ferreira, E. I.; Kubota, L. T., J. Pharm. Biomol. Anal. 2002, 29, 579.

33. Chifotides, H. T.; Fu, P. K.-L.; Dunbar, K. R.; Turro, C., Inorg. Chem. 2004, 43, 1175.

34. Burya, S. J.; Palmer, A. M.; Gallucci, J. C.; Turro, C.rr, Inorg. Chem. 2012, 51,11882 . 